\title{
Telecommunication Reform: The History and Conditions Leading to Political Action
}

\author{
Steve A. Granatat
}

Steve Granata is a master of public administration candidate concentrating in executive, legislative, and regulatory management, with a special emphasis in telecommunications. Mr. Granata is a native of Portland, Oregon, and in 1989 received his bachelor's degree in finance from the University of Maryland at College Park. Mr. Granata works as a contract negotiator on a major federal telecommunications program.

The America of the 1990s is well on its way to becoming the America of the Information Age. Just as assembly lines, factory automation, and mechanical devices characterized the Industrial Revolution, so will megabytes, cyberspace, and bits-per-second reflect the Information Revolution. Computers, fax machines, and electronic mail have become common in workplaces from the Oval Office to the home office. Consumers use information technology every day to pay bills, to keep in touch with friends and family, and to educate and entertain themselves.

The promise of the often publicized and much-vaunted Information Superhighway lies in the convergence of different electronic technologies onto a single platform. In past decades the transmission of television signals, processing of computer data, and carriage of voice telephony were all accomplished with vastly different technologies. The barriers began to fall in the 1980 s with, among other things, the deployment of fiber optic cable. Fiber optics enabled the transmission of digital voice, data, and video on an identical medium.

Today there are many prevalent examples of convergence. Every major telephone company offers a variety of basic and advanced services; several companies have begun trial "video on demand" systems, where consumers use interactive networks to request individual television programs, rather than the traditional method of one-way cable TV. As a result, consumers, businesses, and institutions have become sophisticated users of electronic technology. One can now purchase a home computer that is a combined telephone, television, voice mailbox, electronic mailbox, and fax machine. Similarly, businesses and institutions use information technology for applications such as distance learning, telemedicine, video conferencing, and wide-area data communication.
As technology advances, the cost of facilities and transmission spirals downward. Within a few months or years, the most advanced technology is replaced by something even more sophisticated. Markets for cutting-edge products and services initially are based on economic considerations and comparisons of new technology against existing methods. Therefore, the interaction of technology and economics drives development of the telecommunications industry to a large extent. However, a fundamental component of telecommunication economics is the use of cable right-ofway and the radio spectrum. Consequently, regulatory policy plays an important role in the industry, creating a triangle of technology, economics, and policy.

Although today's technology is on the cutting edge of the Information Superhighway, policy appears to be lagging behind. The Communications Act of 1934 established the basic policy framework over sixty years ago; this was augmented by the 1982 Consent Decree that divested the Bell System. ${ }^{1}$ By most definitions, the speed of technological advancement is outpacing policy development. The Communications Act established dichotomies between various technologies, by regulating different technologies under separate titles. One of the most significant dichotomies is between telephone (Title II) and cable TV (Title VI) regulation. The Consent Decree also placed stringent restrictions on "Baby Bell" line-of-business activities, essentially limiting the companies to the provision of local exchange telephone service.

The structure of today's market is the result of one hundred years of interaction between technology, economics, and policy. For most of that time, telecommunication policy favored a Bell System monopoly on telephone service, while requiring other technologies to develop separately.

As a result, dichotomous markets for telephone, television, and data processing emerged. Even in 1982, divestiture of 
the Bell System brought full competition for long distance telephone, but did not break down other market dichotomies. In the years since divestiture, and to a larger extent the years since passage of the Communications Act, many parties feel that policy has not acknowledged technological convergence sufficiently.

In the early 1990s, several parties began calling for comprehensive reform of the Communications Act and Consent Decree. Industry players joined the White House and Congressional leaders in proposals to break down decades-old barriers between converging digital technologies. The reformed market would be open to full competition between multiple providers of local and long distance telephone, cable TV, and computer data communications. Proponents of reform believe that full competition will bring the yet-undefined Information Superhighway into existence.

\section{Just as assembly lines, factory automation, and mechanical devices characterized the Industrial Revolution, so will megabytes, cyberspace, and bits-per- second reflect the Information Revolution.}

This paper will trace the development of telecommunication policy from its early origins to contemporary proposals for reform. Additionally, the paper will discuss the over seventy-year history of developments leading to the breakup of AT\&T, and the evolution of policies that separated the market into various segments. The latter part of the paper analyzes the potential impact of contemporary proposals on existing market conditions.

\section{Telecommunication Policy}

The principal components of telecommunication regulation are the Communications Act of 1934 and the Modification of Final Judgment (MFJ), the 1982 antitrust settlement that broke up the Bell System. The Modification of Final Judgment is so-named because it modified the 1956 Final Judgment, a previous AT\&T antitrust consent decree. ${ }^{2}$ The Communications Act established the Federal Communications Commission (FCC). This statute maintains the telecommunications regulatory structure, defining federal, state, and local jurisdiction and providing for national policy preemption where necessary. The Communications Act gives the Commission sufficient discretion to act according to the agency's irterpretation of the public interest, corvenience, or necessity. ${ }^{3}$ The FCC is accountable to Congress in a close oversight relationship, and is beholden to the White House through presidential nomination of the five commissioners.

For sixty-nine years, with three antitrust settlements (1913, 1956, and 1982) and continuous federal regulation, the Department of Justice and FCC protected AT\&T's monopoly over the telephone system. The 1913 "Kingsbury Commitment" was the first antitrust settlement, named after an AT\&T Vice President, who entered into the agreement with Attorney General James McReynolds of the Wilson Administration. The settlement came amid antitrust complaints against AT\&T surfacing in the early 1900s, during an era of rejuvenated "trust-busting." AT\&T Chairman Theodore Vail and banker J.P. Morgan pursued an aggressive strategy of buying local exchange telephone companies and adding them to the Bell System. Before the Kingsbury Commitment, AT\&T refused to connect non-Bell (independent) local exchange carriers (LECs) to the long distance network. Therefore, the independents were left isolated and seeking antitrust relief. ${ }^{4}$

To avoid litigation, AT\&T agreed to connect independents to the Bell long distance network. With interconnection and equal access to long distance lines, the independents no longer had an incentive to compete against AT\&T for customers in the same local service area. In a flurry of transactions following the Kingsbury Commitment, AT\&T and the independents swapped local exchange territories until no overlaps existed. Eventually the companies arrived at today's basic market structure: Bell LECs primarily serve metropolitan areas, while independents serve suburban and rural communities. ${ }^{5}$

The 1956 Consent Decree came about primarily because of technological advances and the emergence of Bell Labs as a powerful research and development institution. The 1950s witnessed the beginning stages of computer and telephone system convergence. Large mainframe computers began to resemble digital telecommunications networks, since the flow of traffic between remote terminals and the central processor was similar to traffic on a telephone network. Researchers at Bell Labs recognized the relationship, and AT\&T was well positioned to leverage its dominance for entry into the computer business.

The Department of Justice interceded to stop AT\&T from entering the emerging market for computers. The 1956 Final Judgment simply prohibited AT\&T from any business other than the provision of telephone service and equip- 
ment. ${ }^{6}$ Though the settlement had little impact on AT\&T"s core lines of business, it enabled corporations like IBM and Xerox to dominate the market for data processing in the 1960s and 1970s, where they would not have been viable competitors otherwise.?

One of the most important developments in telecommunication history occurred in 1959 with the FCC "Above-890" decision. This decision allocated a pottion of the UHF radio spectrum above $890 \mathrm{MHz}$, previously available for television broadcasting, for microwave radio transmission. Microwave radio surfaced during World War II, as a result of Bell Labs military research. After the war, major telecommunications users began to find that microwave transmission was less expensive than common-carrier telephone service. By the mid-1950s, users had begun to seek FCC permission to operate private microwave systems on radio frequencies above $890 \mathrm{MHz}{ }^{8}$

\section{Altbough today's technology is on the cutting edge of the Information Superhighway, policy appears to be lagging bebind.}

In 1962, three years after "Above-890," entrepreneur John Goeken and his company Microwave Communications, Inc. (MCI) asked the FCC for permission to operate a public microwave network between Chicago and St. Louis. MCI portrayed its proposed system as a "shared" private network, emphasizing that its total capacity would not be greater than that of any single private system. After protracted deliberations, the FCC approved MCI's application in 1969."

Though the Commission initially ruled on Above-890 because of its jurisdiction over the radio spectrum, MCl's skillful presentation of its proposal as a "shared" private network turned the Above- 890 decision into MCl's chance to compete against AT\&T. By 1971, MCl and a host of competitors filed dozens more applications with the FCC to build microwave lines similar to the Chicago-St. Louis route. Previously, the FCC had used formal adjudicated rulemaking, prescribed by the Administrative Procedure Act (APA), to act on each application. The flood of applications in 1971 forced the Commission to shift to general rulemaking under the APA. In 1971 the FCC issued the Specialized Common Carrier rules, establishing operating parameters for the industry to begin providing private-line telephone service in competition with the Bell System. ${ }^{10}$

In $1975 \mathrm{MCI}$ parlayed the Specialized Common Carrier rules into a service called Execunet. Execunet followed MCl's victory in a bitter regulatory battle against AT\&T over interconnection of private-line service to Bell local exchange facilities. Using this service, customers would dial a local phone number to access the $\mathrm{MCI}$ network. After the customer entered a billing code and the terminating phone number, MCI would transmit the long distance portion of the call to the destination city. At the destination city, MCI used its interconnection rights to terminate the call on the local exchange. "Therefore, through Execunet, MCI established a fully competitive long distance network. The only factors distinguishing MCI from AT\&T were the number and type of locations served, and the amount of digits the caller had to dial to access the network.

By 1976, a year after Execunet, a tide of federal deregulation began to hit Washington. Deregulation shook the status quo of many industries and markets; by the end of the decade, the airline and trucking industries had been deregulated, while the roles of agencies like the Consumer Product Safety Commission and Federal Trade Commission were diminished. Congress actively considered telecommunication deregulation from 1978 to 1980 under the leadership of Congressman Lionel VanDeerlin (D-California), Chairman of the House Communications Subcommittee. Of these legislative efforts, Harvard economist and former FCC Common Carrier Bureau Chief Gerald Brock wrote:

The various market-oriented bills of 1978-1980 were consistent with the general deregulatory approach of the Carter administration and Congress at that time... However, the complexities of the telecommunications problem prevented passage of telecommunication legislation... It was not possible to pass a sweeping deregulation bill similar to the one for the airline industry because local service was widely acknowledged to be an area of continuing monopoly power...any market-oriented bill had to find a way to divide competitive and monopoly areas and prevent cross-subsidy of competitive services by monopoly services. ...Each proposed bill generated a coalition of opponents strong enough to block its passage despite strenuous efforts to find a satisfactory legislative solution...12

In the backdrop of this legislative effort was the federal government's third antitrust suit against AT\&T. The Ford administration filed a complaint in November 1974, after $\mathrm{MCI}$ sued AT\&T over the private-line interconnection con- 
troversy. In the government's complaint, the Department of Justice claimed that AT\&T was abusing its monopoly power, by internally subsidizing local telephone service, long distance telephone service, and equipment manufacturing, rendering head-to-head competition in any one market infeasible. ${ }^{13}$

Ironically, the Bell System established such an internal subsidy structure because of its federally-sanctioned regulated monopoly in each line of business. ${ }^{14}$ However, by the mid1970s neither AT\&T nor the FCC could stop MCI from a practice known as "cream-skimming," whereby MCI eroded the Bell System subsidy structure by competing only in the most profitable long-distance markets. ${ }^{15}$ By allowing $\mathrm{MCI}$ into the market, producing competition on the fringes of AT\&T's monopoly, the FCC slowly drained the lifeblood out of the system that had protected the Bell monopoly for decades.

\section{With today's technology moving toward convergence at a stunning pace, several parties bave begun seeking reform of the Communications Act and repeal of the $\mathrm{MFJ}$.}

With the failure of legislative attempts to deregulate telecommunication, the Reagan administration pursued the 1974 antitrust complaint. For two years, AT\&T and the Department of Justice argued the case before Judge Harold Greene of the U.S. District Court for the District of Columbia. Finally, in 1982, the parties arrived at a settlement that divested the Bell System of the local exchange carriers. Under this regime, local exchange service would continue as a monopoly, while long distance service would be competitive. The underlying objective of divestiture was to segregate monopoly services from those open to competition. Following that logic, AT\&T and the Justice Department created the seven Regional Bell Operating Companies (RBOCs) to provide local service. ${ }^{16}$

While accepting the settlement negotiated privately between AT\&T and the Justice Department, Judge Greene added several RBOC line-of-business restrictions. To prevent the RBOCs from subsidizing other lines of business with profits from monopoly local exchange service, Greene prohibited them from engaging in any manufacturing activity, and maintained the original 1956 restrictions prohibiting them from entry into new markets. AT\&T, the
Justice Department, and Judge Greene agreed to the terms of the Modification of Final Judgment, and entered the Decree on August 24, 1982. ${ }^{17}$ Divestiture went into effect January 1, 1984, and the MFJ has remained in effect ever since.

\section{Telecommunication Reform}

With today's technology moving toward convergence at a stunning pace, several parties have begun seeking reform of the Communications Act and repeal of the MFJ.

Proponents of telecommunication reform contend that the market dichotomies bred by regulation under different titles of the Communications Act and the RBOC line-ofbusiness restrictions in the MFJ inhibit competition and are delaying the economic, social, and political benefits of the Information Superhighway. Consequently, telecommunication reform took a high profile in the 103rd Congress. In the fall of 1993 the Clinton administration's National Information Infrastructure (NII) initiative and the proposed merger of the nation's largest RBOC, Bell Atlantic, and cable TV company, Tele-Communications, Inc. (TCI), became catalysts for legislative action. ${ }^{18}$

In September 1993 the White House unveiled its telecommunication policy in a White Paper called The National Information Infrastructure: Agenda for Action, which called for construction of an Information Superhighway to link schools, libraries, homes, and offices. ${ }^{19}$ In a matter of months, the Information Superhighway became the folklore of newspaper business sections and The Wall Street Journal. Part of the reason the Information Superhighway grew popular so quickly was that it gave the public a convenient point of reference, or label, to understand technological convergence. Computers had come to proliferate in workplaces and educational institutions; consumers encountered information technology when conducting routine business transactions; parents saw their children developing more advanced computer skills than their own; and, most important, it became clear to the public that convergence technology soon would affect how people receive television programming and electronic entertainment.

In 1993 Bell Atlantic sought entry into the market for television by petitioning the U.S. District Court for the Eastern District of Virginia for approval of a plan to carry programming on a "video dial tone" platform. Video dial tone (VDT) is similar in many respects to cable TV, except that to receive programming the viewer "dials out" of a special set-top box rather than having all of the signals transmitted to the receiver simultaneously. VDT uses powerful interac- 
tive digital switches not present in standard cable networks. In August 1993 the District Court granted Bell Atlantic's request, a ruling subsequently upheld by the U.S. Court of Appeals for the Fourth Circuit. ${ }^{20}$

When combined with the TCI merger, Bell Atlantic's court victory threatened to tear down the regulatory dichotomy between telephone and cable TV. Under the merger, TCI, a cable company, would cease to exist. Thus, TCI would avoid the Title VI restriction on cable and telephone company cross-ownership. At the same time, Bell Atlantic, the surviving company, had permission to provide both television and telephone service. ${ }^{21}$ Therefore, the combined Bell Atlantic-TCI could legally provide hybrid telephone and television service in their previously overlapping service areas.

\section{Part of the reason the Information Superbighway grew popular so quickly was that it gave the public a convenient point of reference, or label, to understand technological convergence.}

The Bell Atlantic-TCI merger failed several months after its announcement. Many observers blame the companies' sharply contrasting corporate cultures and leadership styles, while others fault FCC cable rate regulation under the 1992 Cable Consumer Protection and Competition Act. Whatever the true reasons, the merger's failure is of sufficient magnitude to warrant further study. However, the $\$ 25$ billion deal did spur action on Capitol Hill. With the potential breakdown of regulatory dichotomies among different technologies, and implicit pressure to alleviate $\mathrm{RBOC}$ lineof-business restrictions, Congressional leaders were under pressure to reform telecommunication policy before the industry itself circumvented the existing regulatory scheme. ${ }^{22}$

In the 103rd Congress, the House and Senate considered four significant telecommunication bills. H.R. 3626 and 3636, and S. 1822 and 2111 were companion legislation introduced with bipartisan support. The primary House sponsors were Representatives Jack Brooks (D-Texas), Chairman of the Judiciary Committee, and John Dingell (R-Michigan), Chairman of the Commerce Committee. ${ }^{23}$ In the Senate, the primary sponsors included Commerce Committee Chairman Ernest Hollings (D-South Carolina), ${ }^{24}$ and Committee Members John Breaux (D-Iouisiana) and
Bob Packwood (R-Oregon). ${ }^{25}$

Telecommunication reform did not pass the 103rd Congress for the same reasons it failed in the 96th Congress: the bills created an incorrigible mix of winners and losers. Legislative efforts in the 103rd Congress addressed five telecommunication policy issues: allowance of telephone companies into cable TV, competition in local exchange telephone service, RBOC entry into long distance, public utilities entry into telecommunications, and entry of RBOCs into manufacturing. However, each provision simultaneously created a winner without necessarily giving the loser an offsetting benefit. Each of the issues is described below, as it was addressed in the 103rd Congress legislation. Although Congress failed to enact any reforms, the five issues will shape debate over telecommunication reform for years to come. Furthermore, in the future any of them could be addressed by the justice system, FCC, Congress, or state legislatures. Therefore, the following analysis addresses each of the issues independently, rather than as a complete package.

\section{Telephone and Cable TV Cross-Entry}

This legislative proposal would amend the Communications Act to do away with the regulatory dichotomy between telephone and cable TV companies. Telephone and cable TV operators currently are regulated by separate and distinct schemes, where each is confined to its segment of the market. This option would allow companies to build Bell Atlantic-TCI style information highways without having to skirt geographic borders or avoid regulatory restrictions. ${ }^{25}$ Since telephone companies have powerful electronic switches and cable companies have high-capacity one-way transmission capabilities, both would benefit from uniting their respective technologies.

On the surface, this policy seems to benefit telephone and cable companies equally. Clearly, it would remove significant technological and economic barriers to convergence technology. However, this policy allows for competition in the local exchange. Therefore, in many markets the RBOCs and cable TV companies most likely would choose to compete against each other by upgrading their networks, rather than electing to cooperate in mergers and joint ventures. Phone companies would serve their customers on a video dial tone platform, while cable companies would install switching equipment and carry service on their installed base of coaxial television cable.

The competitive situation would be especially dramatic in 
major urban areas, where high-density customers cause substantivl economies of scale. The result of this scenario is the potential for markets with either one dominant carrier and one or more weak carriers, or markets with no competition at all. The carrier able to achieve the highest scale economy would likely drive other carriers out or force them into weak competitive positions. In the worst case, the dominant carrier would "cherry-pick" the most profitable segments of the market, leaving high-cost service areas to non-dominant firms.

\section{Competition for Local Exchange Telephone Service}

In addition to the potential entry of cable TV companies into the market, a burgeoning industry of "alternate access vendors" (AAVs) already connect phone lines from customers' premises directly to long distance network access points, bypassing the regular local exchange carrier (LEC). AAVs typically cater to large long distance users in metropolitan areas. Because AAVs only operate in LECs' most profitable markets, they undercut LEC prices.

\section{Telecommunication reform did not pass the 103rd Congress for the same reasons it failed in the 96th Congress: the bills created an incorrigible mix of winners and losers.}

To show how alternative access service works, one can take the example of an AAV operating in Washington, D.C. Assume that a financial institution, which is a significant long distance customer, occupies a downtown office building. Further assume, for example, that the financial institution has chosen Sprint as its long distance company. The AAV will connect all of the customer's phone lines directly from the office building to a nearby Sprint network access point, bypassing Bell Atlantic, Washington's LEC. The AAV can undercut Bell Atlantic's prices because Bell Atlantic, like the former Bell System, charges flat rates and subsidizes high-cost service with low-cost service. In this example, the AAV is "cream-skimming" one of Bell Atlantic's most profitable markets: concentrated office buildings in a downtown area. AAVs cream-skim RBOC local exchanges the same way MCI cream-skimmed AT\&T"s most profitable long distance markets in the 1970s.

Using alternative access technology, AAVs can connect cus- tomers' telephones to local exchange switches as easily as they now connect customers to long distance networks. The only factor prohibiting this type of service is telecommunication policy. Legislation proposed during the 103rd Congress would have required the RBOCs to interconnect their local exchanges with competitive providers, including AAVs, cable TV companies, and even long distance carriets. The rules would have forced the RBOCs to give competitive providers interconnection that was technically equivalent to the local exchange service RBOCs provide directly to their own customers. Furthermore, new regulations would have mandated customer telephone number portability between competitive providers, alleviating concerns over the possibility of having to change numbers to change companies. ${ }^{27}$

Although this policy would create considerable competition for local exchange service, in some markets it has the potential for a significant win-lose situation. The above example of AAV cream-skimming could be repeated several times over in every metropolitan area, potentially leaving the RBOCs only with high-cost territories and no way to generate subsidies with profits from lower-cost service. For this policy to be feasible, the RBOCs would need an offsetting benefit. The most apparent offset would be to repeal the MFJ restriction on long clistance service, allowing the RBOCs to sell packaged local exchange and long distance service, thereby cushioning the impact of lost long distance network access revenue.

\section{RBOC Entry into Long Distance}

Another part of the 103rd Congress legislation would have allowed for both competition in local exchange service and RBOC entry into the market for long distance. Under today's regime, for example, a call between Baltimore and Philadelphia must be carried by a long distance company such as AT\&T, MCI, or Sprint, even though both cities are in Bell Atlantic's service territory. Under this proposal, however, Bell Atlantic would be free to compete against long distance companies for the service.

S.1822 would have allowed an RBOC to enter the market for long distance service, provided the RBOC passed four tests administered by the Department of Justice and FCC. Congress intended the tests to ensure that a proper level of local exchange competition existed before an RBOC entered the market for long distance. ${ }^{2 x}$ However, the preconditions specified in the bill were too ambiguous to define clearly when a local exchange would be considered fully competitive. While S.1822 contained a clate-certain for 
$\mathrm{AAV}$, cable, and long distance company entry into local exchange service, the regulatory tests left the RBOCs uncertain about when they could go into long distance.

As with proposals for local exchange competition, allowing RBOCs to enter the market for long distance would create a powerful win-lose situation; however, unlike local service, the situation could cut two ways. In one scenario, the RBOCs could win while long distance companies lose. Since the bulk of long distance calling is within a few hundred miles of the customer's location, RBOCs could carry those calls on their networks with almost no modification of existing facilities. RBOC long distance service would begin soon after authorization, in an extremely efficient and competitive manner. Long distance companies quickly would lose considerable market share before they became significant players in the local exchange.

In the other scenatio, the RBOCs could find themselves facing local exchange competition before having passed regulatory tests allowing them to enter long distance. This possibility caused RBOC lobbyists to oppose the final version of S.1822 in the 103rd Congress. During the 104th Congress, discussion arose over the possibility of a datecertain approach to simultaneous opening of both markets to competition. The date-certain approach does not alleviate concerns about the definition of full local exchange competition, nor does it address contingencies when local competition fails to appear. With this policy alternative, there is not a clear winner or loser, nor is there any effective way to ensure that losers are compensated with a comparable benefit. The complexity of this dilemma illus- . trates the difficulty in finding adequate telecommunication reform alternatives.

\section{Entry Into Telecommunications by Electric and Other Utility Companies}

S.1822 also contained an amendment to the Public Utility Holding Companies Act of 1935 (PUHCA), which prohibits a registered public utility company from engaging in businesses not directly related to the company's core provision of utility service. ${ }^{29}$ Enactment of this provision would be one of the most sweeping changes in the history of both telephone and non-telephone public utility service.

The Energy Policy Act of 1992, which separated the transmission of electricity from its bulk generation, prompted heavy power consumers to begin using electronic Demand-Side Management (DSM) systems to curtail electric consumption during hours of peak demand. DSM sys- tems are geographically-dispersed digital data communication networks that monitor consumption of electricity on a power grid. A factory, for example, can use a DSM system to boost assembly line production during off-peak hours. ${ }^{30}$ DSM systems can be easily modified to carry telecommunication traffic. In the above example, the factory could connect its internal telecommunications system to the DSM network, and use it to carry digital voice, data, and video. With interconnection, DSM network providers could compete for service against local and long distance telecommunication companies.

\section{Manufacturing Authority for RBOCs}

Another section of the legislation proposed during the 103 rd Congress would have overturned the MFJ RBOC manufacturing restriction. ${ }^{31}$ Many observers view the manufacturing prohibition as the most restrictive part of the MFJ, and would like to see it removed. Other analysts see the restriction as a fundamental measure protecting monopoly local exchange service from cross-subsidy. Still another viewpoint favors the manufacturing restriction not to protect against cross- subsidies, but as a method to ensure that manufacturers bring the latest technology to market independently.

The emergence of competition on the fringes of local exchange telephone service has begun a spiral of events that will lead to construction of the yet undefined Information Superbighway.

The Consent Decree prohibited the RBOCs from all types of manufacturing activity, including not only the fabrication of equipment but all research and development. Ten years later, with technological convergence, the RBOCs protest the manufacturing restriction because they want to participate in the design and clevelopment of devices used to build their networks. As US West Chairman Richard McCormick explained in Senate testimony, service companies must collaborate closely with equipment makers to develop advanced technology:

The set-top box and video servers it will take to make multi-media [hybrid telephone-television] a reality aren't available from "off the shelf." They're still in the laboratory where engineers are trying to get the bugs out of them. The restrictions severely 
compromise our ability to engage in design discussions with manufacturers...

Whenever one of our people has a good idea, that individual must share [it] with a battery of attorneys who make their best judgment as to whether carrying [it] forward would violate the MFJ...They don't let their imaginations run as freely. They're not as creative.

They're more disappointed than entrepreneurial..$^{32}$

The MFJ restricts the RBOCs in everything from low-level technical discussions with manufacturers to participation in joint business ventures. While the MFJ succeeded in divesting the Bell System of Western Electric, its manufacturing subsidiary, today the manufacturing prohibition is not serving such a clear purpose. Proponents of the restriction feel that it prevents RBOCs from holding the latest technology "on the shelf" until they can fully depreciate existing network assets and facilities. Another school of thought, however, feels that with adequate competition the market will give companies sufficient incentive to deploy the latest equipment.

\section{Analysis \& Conclusions}

The emergence of competition on the fringes of local exchange telephone service has begun a spiral of events that will lead to construction of the yet undefined Information Superhighway. Although there has been much talk of telecommunication reform and a tremendous amount of attention paid to convergence technology, the Information Superhighway has yet to emerge in a congruent form. While we see many individual information highways in wide area computer systems, long distance telephone networks, cable TV systems, and the Internet, market dynamics have not evolved to the point where multiple competitors provide all these services on a single conduit.

But the beginning of competition on the fringes of the most profitable local exchange services will change this. Today the AAVs are cream-skimming RBOC profits the same way $\mathrm{MCI}$ and early long distance competitors creamskimmed AT\&T's long distance routes. Cable operators and long distance companies are poised to enter the local exchange when policy permits.

All of this competition promises to drive local exchange pricing structures to levels that accurately reflect the true cost of service. Today, discerning the relationship between local exchange costs and prices is difficult, because rate-ofreturn regulation encourages telephone companies to charge flat rates with implicit subsidies. In the future, local exchange carriers will be competing in a high-tech multiservice environment, providing various combinations of individual service elements. In this environment, competition-not rate-of-return regulation-will determine specific service prices. To achieve economies of scale, telecommunication companies will be forced to provide economically attractive "packages" of service.

\section{All of this competition promises to drive local exchange pricing structures to levels that accurately reflect the true cost of service.}

Packages will consist of combinations of local and long distance telephone, interactive video, and data communications service. They will be available in a variety of "tiers," catering to a range of customers from large organizations to residential consumers. As these multi-service packages emerge, they will change telephone, television, and computer service into a technologically-converged digital Information Superhighway. Competitive packages of broadband interactive multimedia services will be available on a single conduit, from several providers. As this occurs, the National Information Infrastructure will come into existence.

The growing amount of local exchange competition makes telecommunication reform as inevitable today as it was in the late 1970s and early 1980s. Events in that era showed that telecommunication reform was too complex to be solved with incremental policy change, hence the failure of legislation in the 96th Congress and, ultimately, divestiture. With the MFJ, a small group of people, in a seven-page document, accomplished what the entire legislative branch of the United States could not do in two years. The incorrigible mix of winners and losers in today's incremental policy proposals presents the same dilemma.

Unlike the situation in the late 1970s and early 1980s, though, today's telecommunication reform effort is centered in Congress. The Department of Justice and the FCC do not have nearly the roles they had in the events preceding divestiture. The traditionally deliberative legislative process is confounded by a Congress bent on finding solutions favorable to lobbyists on both sides.

In early January 1995, the Clinton Administration held a federal/state/local telecommunication policy "summit" in Washington, timed to coincide with the beginning of the 104th Congress. At the conference, Vice President Gore 
summarized the telecommunication reform dilemma and called on Congress to break the gridlock:

The issuance of our Joint Statement [federal-statelocal]...comes at a critical...time as Congress begins debate over new telecommunications legislation, [and] as state and local governments...[build] increasing momentum to open markets... The framework we issue today... will send a clear signal that our resolve for revolutionary change is greater [now] than ever before. ${ }^{33}$

With the MFJ, a small group of people, in a seven-page document, accomplished what the entire legislative branch of the United States could not do in two years.

Several states have passed some form of intrastate telecommunication deregulation, allowing for various degrees of competition in the local exchange. New York was one of the first states to allow such competition: trials are underway in Rochester and New York City. ${ }^{34}$ The nation is watching as the New York Public Service Commission deals with new regulatory challenges every day, in what is becoming a national model for full deregulation and competition. In this respect, Congressional gridlock is advantageous since it allows states to be laboratories for national policy. The disadvantage of federal followership is that the entire country must wait for unified policy. Since the
Information Highway is by its nature interstate, the government must present federal policy guidance in order for this complex system to fully develop (federal meaning unified policy for all levels of government, instead of rudimentary jurisdictional preemption).

In order for telecommunication reform to be successful, Congress must take a non-incremental approach to change. Regarding potential winners and losers, Gore said:

Each industry is trying to enter new markets while keeping competitors out of its own old market. The motto seems to be, "What's mine is mine-what's yours is negotiable." We have to break this impasse if we are going to create a vibrant, competitive information marketplace...How do we reconcile all these fears [of new competition]?... only by having the courage to throw out the regulated monopoly model... and instead create a truly competitive marketplace where regulation is replaced by competition.... ${ }^{35}$

Although each increment appears to create too many winners and losers, a fully reformed market will have nothing but winners. The telecommunications industry will grow like the major conglomerates of the industrial era in the early 20th century. Full competition will bring convergence technology into our homes, offices, schools, libraries, and hospitals. We will find new applications for information technology that we cannot imagine today. A high-tech revolution will create the America of the 21st century, an America of the Information Age. $\star$

\section{Notes}

II especially wish to thank Professors Gerald Brock and Jill Kasle of The George Washington University for their academic inspiration and direction. I would also like to thank the following: $\mathrm{Mr}$. James Spurlock of AT\&T, who was an outstanding referee; Mr. John Gosnell of the General Services Administration, for his economic perspective; Mr. Mark Langsam of the General Services Administration, for his policy perspective; and my colleagues Mr. Jeremy Azif and Ms. Valerie Herold, for their expert advice and counsel. I am deeply indebted to my editor, Deirdre McGlone, and associate editor, Julie Kotzin, for holding my work to the highest academic standards.

${ }^{1}$ Gerald W. Brock, Telecommunications Policy for the Information Age (Cambridge: Harvard University Press, 1994), 50.

${ }^{2}$ United States $v$ American Telephone and Telegraph Company, 552 F.Supp. 131 (1982), 460 US 1001, 103 S.Ct. 1240 (Modification of
Final Judgment).

Brock, 52.

Ibid., 65-66

sIbid.

${ }^{6}$ United States v Western Electric, 1956 Trade Cases (CCH) $\$ 68,246$ (1956) (Final Judgment [Consent Decree]).

'Robert Frieden, "The Computer Inquiries: Mapping the Communications/Information Processing Terrain," Federal Communications Law Joumal 33, no.1, (Winter 1981): 105-106.

Brock, $105-111$.

Ibid., 111-113.

${ }^{10}$ Tbid., $116-117$. 
"Ibid., $122-127$.

${ }^{12}$ Ibid., 152.

13Ibid., $152-156$.

${ }^{14}$ Ibid.

${ }^{15}$ Ibid., $124-126$.

I'Ibid, 162.

${ }^{17 M o d i t i c a t i o n ~ o f ~ F i n a l ~ J u d g m e n t . ~}$

"Daniel Pearl, "Spurred by Bell-TCI Deal, Congress Moves "Toward Ending Cable-TV Phone Barriers," The Wall Street Joumal, 21 October 1993, A20.

"White House White Paper, "The National Information Infrastructure: Agenda for Action," 15 September 1993.

${ }^{20}$ Grutam Naik, "Bell Atlantic Wins Right to Transmit Video by Phone," The Wall Street Journal, 22 November 1994, B8.

${ }^{2}$ Dennis Kneale, Johnnie L. Roberts, Laura Landro, "Bell Atlantic and TCI Are Poised to Shape a New Interactive World," The Wall Street foumal, 14 October 1993, A1.

${ }^{22}$ Pearl, A20.

${ }^{2 x}$ House Report, Antitrust and Communications Reform Act of 1994, 103d Cong., 2d sess., 24 June 1994.
${ }^{24}$ Senate Report, Communicationts Act of 1994, 103d Cong., $2 \mathrm{~d}$ sess., 14 September 1994.

${ }^{25}$ Telecommunications Service Enbancement Act of 1994, 103d Cong., 2d sess., S. 2111.

"Communications Act of 1994.

${ }^{27}$ Ibid.

${ }^{28}$ Ibidl.

"Ibid.

${ }^{30}$ Daniel Sutherland, "Future Shock: A Choice of Utilities," The Washington Post, 27 November 1994, H1.

${ }^{31}$ Communications Act of 1994.

${ }^{34}$ Senate Committee on Commerce, Science and Transportation, Testimony of Mr. Richard MCCormick, Chairman and CEO of US West on S.1822, 17 March 1994. 103d Congress 2d Session. Congressional Record, 1994, vol. 140, 271.

${ }^{33}$ White House Press Release, "Remarks by Vice President Gore at the Federal-State-Local Telecomm Summit," 9 January 1995.

${ }^{3}$ Anne K. Bingaman, "Promoting Competition in Telecommunications," Address before the National Press Club, Washington, DC, 28 February 1995.

${ }^{3}$ Remarks by Vice President Gore at the Federal-State-Local Telecomm Summit.

United States $v$ American Telephone and Telegraph Company, 552 F.Supp. 131 (1982), 460 US 1001, 103 S.Ct. 1240 (Modification of Final Judgment).

United States $v$ Western Electric, 1956 Trade Cases (CCH) 168,246 (1956) (Final Judgment [Consent Decree]).

United States Senate Committee on Commerce, Science and Transportation. Testimony of Mr: Richard McCormick, Chairman and CEO of US West on S.1822, 17 March 1994. 103d Congress 2d Session. Congressional Record, 1994, vol. $140,271$.

White House, Press Release. "Remarks by Vice President Gore at the Federal-State-Local Telecomm Summit." 9 January 1995.

White House, White Paper. "The National Information Infrastructure: Agenda for Action." September 1993.

Sutherland, Daniel. "Future Shock: A Choice of Utilities." The Wasbington Past. 27 November 1991. 